\title{
Understanding Hypernatremia
}

\author{
Ramin Sam ${ }^{a} \quad$ Iraj Feizi $^{b}$ \\ ${ }^{a}$ Division of Nephrology, San Francisco General Hospital and the University of California, San Francisco, Calif., USA; \\ ${ }^{b}$ Division of Surgery, Ardabil University of Medical Sciences, Ardabil, Iran
}

\section{Key Words}

Hypernatremia $\cdot$ Hyponatremia $\cdot$ Sodium and water balance

\begin{abstract}
Understanding hypernatremia is at times difficult for many clinicians. However, hypernatremia can often be deciphered easily with some basic understanding of water and sodium balance. Here, the basic pathophysiological abnormalities underlying the development of sodium disorders are reviewed, and case examples are given. Hypernatremia often arises in the hospital, especially in the intensive care units due to the combination of (1) not being able to drink water; (2) inability to concentrate the urine (most often from having kidney failure); (3) osmotic diuresis from having high serum urea concentrations, and (4) large urine or stool outputs.
\end{abstract}

Copyright $\odot 2012$ S. Karger AG, Basel

\section{Why Are Serum Sodium Concentration Problems Difficult?}

Hyponatremia and hypernatremia are commonly encountered problems both in the outpatient setting and especially in hospitalized patients. Frequently, confusion arises as to how best manage these patients with serum sodium concentration abnormalities. In the case of hy- pernatremia not only how much fluid to give is questioned but also what kind of fluid. With hyponatremia, the problem is usually figuring out what has led to the abnormal serum sodium concentration. In order to undo some of this confusion, one first needs to understand why sodium concentration problems are so difficult.

Sodium concentration problems are difficult because as far as sodium is concerned the body is comprised of at least two compartments (the extracellular and the intracellular fluid). If one imagines a one-compartment system where sodium concentration is same in the total body water, sodium concentration problems would be simple (fig. 1). In a one-compartment system, the serum sodium concentration is equal to total body sodium divided by total body water.

$[\mathrm{Na}]=$ total body $\mathrm{Na} /$ total body water (in a one-compartment system)

Imagining this one-compartment system, if the serum sodium concentration is for example $160 \mathrm{meq} / \mathrm{L}$ and total body water is 40 liter, one can easily see that administering 5.7 liter of pure water will lower the serum sodium concentration to $140 \mathrm{meq} / \mathrm{L}$ (assuming that there is no sodium or water loss, and no sodium intake). Again, in a one-compartment system if one starts out with a serum sodium concentration of $140 \mathrm{meq} / \mathrm{L}$ (total body water 40 liter), makes 2 liter of urine with sodium concentration of $40 \mathrm{meq} / \mathrm{L}$ in $24 \mathrm{~h}$, and has no intake, then the serum so-

\section{KARGER}

Fax +41613061234

E-Mail karger@karger.ch

www.karger.com (c) 2012 S. Karger AG, Basel

0250-8095/12/0361-0097\$38.00/0

Accessible online at:

www.karger.com/ajn
Ramin Sam, MD

San Francisco General Hospital

1001 Potrero Ave, Building 100, Rm 349

San Francisco, CA 94110-1341 (USA)

Tel. +1 415206 6605, E-Mail samr@medsfgh.ucsf.edu 


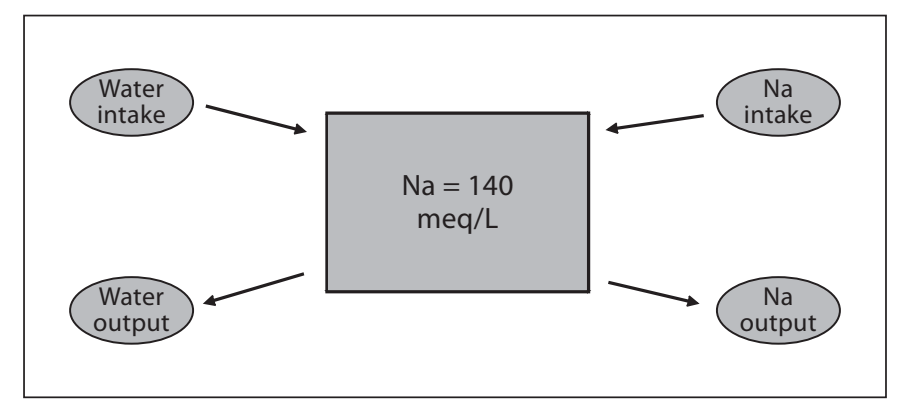

Fig. 1. Sodium concentration in a one-compartment system.

dium concentration at the end of the 24-hour period would be $145 \mathrm{meq} / \mathrm{L}$. In summary, in a one-compartment system, all sodium concentration problems can be solved by knowing few simple facts (serum sodium concentration, total body water, urine volume, urine sodium concentration, sodium intake and water intake).

\section{How to Make a One-Compartment System Out of Two Compartments}

However, body fluid is not a one-compartment system as far as sodium is concerned, but it is composed of at least two compartments (fig. 2). In 1958, Edelman et al. [1] came up with a brilliant idea of making a onecompartment system out of two compartments. Since intracellular potassium concentration is almost the same as extracellular sodium concentration and vice versa, they postulated that serum sodium concentration is proportional to total body sodium plus potassium divided by total body water $([\mathrm{Na}]=$ (total body $\mathrm{Na}+$ total body $\mathrm{K})$ /total body water). They tested their idea and found good results (correlation coefficient of $r=0.83$ ). Put another way, when we take in potassium which goes mostly intracellularly, the serum sodium concentration will increase by movement of water (and not of sodium) from extracellular space to intracellular space [1-3]. As an example, if one has a baseline serum sodium concentration of $140 \mathrm{meq} / \mathrm{L}$ and has total body water of 40 liter, then the total body sodium plus potassium will be 5,600 meq. If in the next $24 \mathrm{~h}$ that person makes 2 liter of urine which has a sodium concentration of $40 \mathrm{meq} / \mathrm{L}$ and a potassium concentration of $40 \mathrm{meq} / \mathrm{L}$ also and has no intake, then the serum sodium concentration will be $143 \mathrm{meq} / \mathrm{L}$ at the end of the 24-hour period. Understanding that this formula is not exact because of a variety of reasons is im-

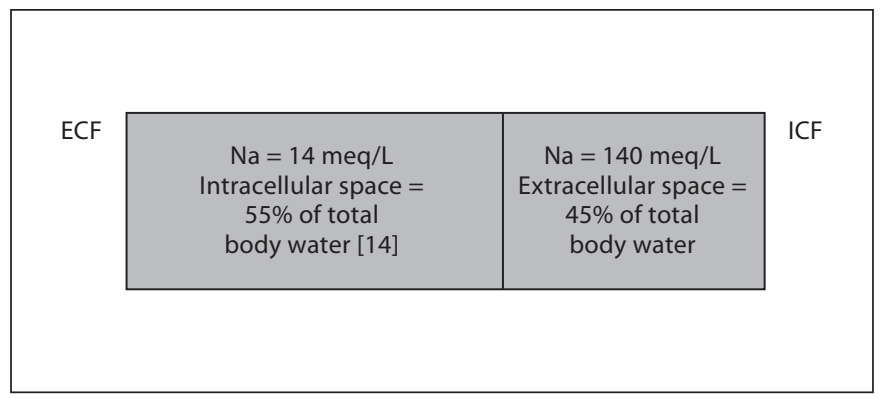

Fig. 2. A two-compartment model.

portant. In this system, one will need the total body water, intake of potassium, sodium, and water, output of potassium, sodium and water and beginning serum sodium concentration to solve the sodium concentration problem.

\section{The Other Compartments}

Because of the Gibbs-Donnan effect, and the fact that electro-neutrality has to be maintained both in the intravascular and in the interstitial fluid, the interstitial fluid has a sodium concentration slightly less than the intravascular fluid (139 meq/L rather than $142 \mathrm{meq} / \mathrm{L}$ ) [4]. The Gibbs-Donnan effect arises from the fact that the serum albumin concentration is higher in the intravascular fluid than the interstitial fluid. Thus, in order to maintain electroneutrality, as albumin is net negatively charged, there has to be a little more sodium in the intravascular space than the interstitial space. Thus, the interstitial fluid will constitute a third compartment.

The fourth compartment is the sodium bound to proteins, stored in the skin or in the bone which is in equilibrium with the rest of the body sodium but is not osmotically active [5]. This compartment also contributes to the serum sodium concentration as it has an effect on the ability of sodium intake to raise serum sodium concentration. For instance, if this compartment did not exist, intake of 100 meq of $\mathrm{NaCl}$ may increase serum sodium from 142 to $144 \mathrm{meq} / \mathrm{L}$, but now 120 meq of $\mathrm{NaCl}$ is necessary to cause the same increase in serum sodium concentration because 20 meq of the $\mathrm{NaCl}$ given, has been stored in the skin. The last compartment is the sodium deep inside the bone which is not in equilibrium with the rest of the body water sodium and is not a determinant of serum sodium concentration. 


\section{Modifications of Edelman's Equation}

The original Edelman equation is: $\mathrm{S}_{\mathrm{Na}}=1.11$ (total body $\mathrm{Na}+$ total body $\mathrm{K}$ )/total body water -25.6 [1]. This equation was simplified in 1986 by Rose to $S_{\mathrm{Na}}=$ (total exchangeable body $\mathrm{Na}+$ total exchangeable body $\mathrm{K}$ )/total body water [6]. The modified formula has become the preferred formula clinically, and from it the electrolytefree water excretion formula is derived. The formula for electrolyte-free water excretion is $\mathrm{V} \times\left\{1-\left(\mathrm{U}_{\mathrm{Na}}+\mathrm{U}_{\mathrm{K}}\right)\right.$ / $[\mathrm{Na}]\}$, where $\mathrm{V}$ is the flow rate of urine. This formula determines if part of the urine has the same sodium plus potassium concentration as the serum sodium concentration, how much urine is just free water. For example, if urine output is $2 \mathrm{l} / \mathrm{day}$, urine $\mathrm{Na}$ concentration is 35 $\mathrm{meq} / \mathrm{L}$, urine potassium concentration is also $35 \mathrm{meq} / \mathrm{L}$, and serum sodium concentration is $140 \mathrm{meq} / \mathrm{L}$, then half of the urine has a urine sodium plus potassium concentration of $140 \mathrm{meq} / \mathrm{L}$ (the same as the serum sodium concentration) and half of the urine is just free water. Thus the electrolyte-free water excretion would be $1 \mathrm{l} /$ day, meaning that the patient needs to drink $11 /$ day of free water to keep the serum sodium concentration the same.

More recently, Kurtz and Nguyen have tried to make sense of slope and the y-intercept of the original Edelman formula, and have derived more complicated formulas [7-8]:

$$
\begin{aligned}
{\left[\mathrm{Na}^{+}\right]_{\mathrm{pW}}=G / \varnothing \frac{\left(\mathrm{Na}_{\mathrm{e}}+\mathrm{K}_{\mathrm{e}}\right)}{\mathrm{TBW}}-\mathrm{G} / \varnothing\left[\frac{\left(\mathbf{N a}_{\text {osm inactive }}+\mathbf{K}_{\text {osm inative }}\right)}{\mathrm{TBW}}-\right.} \\
\left.\frac{\left(\mathbf{o s m o l}_{\mathrm{ICF}}+\mathbf{o s m o l}_{\mathrm{ECF}}\right)}{\mathrm{TBW}}+\left[\mathbf{K}^{+}\right]_{\mathrm{pw}}+\frac{\text { osmol }_{\mathrm{pw}}}{\mathbf{V}_{\mathrm{pw}}}\right]
\end{aligned}
$$

where

$$
G=\frac{\left(\mathrm{V}_{\mathrm{pw}}+\mathrm{V}_{\mathrm{ISF}}\right)}{\mathrm{V}_{\mathrm{pw}}+0.95 \times \mathrm{V}_{\mathrm{ISF}}}
$$

pw = plasma water, $\mathrm{Na}_{\mathrm{e}}=$ exchangeable $\mathrm{Na}, \mathrm{K}_{\mathrm{e}}=\mathrm{ex}-$ changeable potassium, $\mathrm{G}=$ Gibbs-Donnan effect, $\mathrm{TBW}=$ total body water, $\varnothing=$ osmotic coefficient of $\mathrm{Na}^{+}$salts, $\mathrm{Na}_{\text {osm inactive }}=$ osmotically inactive sodium, $\mathrm{K}_{\text {osm inactive }}=$ osmotically inactive potassium, osmol $_{\mathrm{ICF}}=$ osmotically active non-sodium and non- potassium intracellular os-

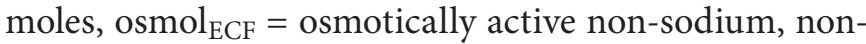
potassium extracellular osmoles, $\mathrm{V}_{\mathrm{pw}}=$ plasma water volume, $V_{\text {ISF }}=$ interstitial fluid volume.

In this equation, $G$ is about 1.04. $\varnothing$ is for the fact that sodium salts do not completely dissolve in plasma and thus the osmolality of $\mathrm{Na}^{+}$is not exactly one but about
0.94. $\mathrm{G} / \varnothing$ is thus 1.11 , which is the slope of the original Edelman's equation.

Most of the equation (the portion in bold) reflects the $y$-intercept of 25.6. First, if sodium salt is given, and this sodium goes inside the osmotically inactive part of the bone or is osmotically inactive bound to serum proteins, then it will not raise the serum sodium concentration and thus needs to be subtracted from the calculated serum sodium concentration. This sodium does contribute to the serum sodium concentration though because now we need more sodium intake to have the same effect on the serum sodium concentration. Second, if we give a substance that goes intracellularly or interstitially, that substance will raise the serum sodium concentration by drawing water out of the intravascular space and thus raise the serum sodium concentration (much in the same way as potassium administration). Third, any substance (other than sodium) given that stays intravascularly (including the small portion of the potassium given) will tend to lower the serum sodium concentration by drawing water into the intravascular space.

\section{Are Sodium and Potassium Completely Equivalent in Determining Serum Sodium Concentration?}

Edelman's equation assumes sodium and potassium are completely equivalent in determining serum sodium concentration. However, this is unlikely to be the case, although they may be fairly close to being equivalent. In order to try to answer this question, one has to assume several factors: (1) a two-compartment system for sodium; (2) ions (sodium) having an osmolality of one (complete dissolution of ions in the plasma); (3) complete osmotic equilibrium between intravascular, interstitial and intracellular fluids (may not be complete because of the Gibbs-Donnan effect); (4) the nonexistence of non-osmotically active sodium and potassium; (5) no intercompartmental movement of sodium or potassium with administration of potassium or sodium, respectively, and (6) intracellular fluid constitutes $55 \%$, extracellular fluid constitutes $45 \%$ of total body water [9].

With the above assumptions, if one makes a further assumption that all of the administered $\mathrm{KCl}$ will go intracellularly and all of the administered $\mathrm{NaCl}$ stays extracellularly, then giving $100 \mathrm{meq}$ of $\mathrm{KCl}$ will raise the serum sodium concentration from 142 to $144.4 \mathrm{meq} / \mathrm{L}$ (fig. 3). If one gives 100 meq of $\mathrm{KCl}(100$ mosm $\mathrm{K}, 100$ mosm $\mathrm{Cl})$, that would raise the plasma osmolality from 300 to 305 mosm/l, as there are now 200 more mosms $\{[(300$ mosm $/ 1$ 
Fig. 3. Electrolyte concentration before and after administration of $100 \mathrm{meq}$ of KCl. Assuming: (1) two-compartment model, (2) ionic osmolality of 1.0, (3) complete osmotic equilibrium between the compartments, (4) all administered $\mathrm{KCl}$ goes intracellularly, (5) no intercompartmental movement of $\mathrm{Na}$ with $\mathrm{K}$ administration. Ignoring: (1) Gibbs-Donnan effect, (2) non-osmotically active $\mathrm{Na}$ and $\mathrm{K}$. Fig. 4. Electrolyte concentrations before and after administration of $100 \mathrm{meq}$ of $\mathrm{NaCl}$. Assuming: (1) two-compartment model, (2) ionic osmolality of 1.0, (3) complete osmotic equilibrium between the compartments, (4) all administered $\mathrm{NaCl}$ goes extracellularly, (5) no intercompartmental movement of $\mathrm{K}$ with $\mathrm{Na}$ administration. Ignoring: (1) the Gibbs-Donnan effect, (2) non-osmotically active $\mathrm{Na}$ and $\mathrm{K}$.

5

Fig. 5. Electrolyte concentration before and after administration of $100 \mathrm{meq}$ of $\mathrm{KCl}$. Assuming: (1) two-compartment model, (2) ionic osmolality of 1.0, (3) complete osmotic equilibrium between the compartments, (4) $\mathrm{KCl}$ distributes in intracellular and extracellular fluids, (5) no intercompartmental movement of $\mathrm{Na}$ with $\mathrm{K}$ administration. Ignoring: (1) the Gibbs-Donnan effect, (2) non-osmotically active $\mathrm{Na}$ and $\mathrm{K}$.

Fig.6. Electrolyte concentrations before and after administration of 100 meq of $\mathrm{NaCl}$. Assuming: (1) two-compartment model, (2) ionic osmolality of 1.0, (3) complete osmotic equilibrium between the compartments, (4) $\mathrm{NaCl}$ distributes in intracellular and extracellular fluids, (5) no intercompartmental movement of $\mathrm{K}$ with $\mathrm{Na}$ administration. Ignoring: (1) the Gibbs-Donnan effect, (2) non-osmotically active $\mathrm{Na}$ and $\mathrm{K}$.
3

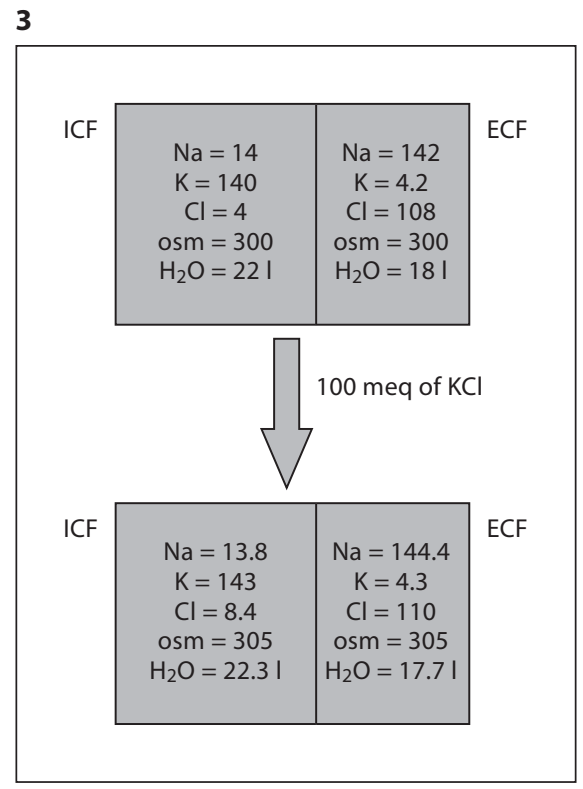

4
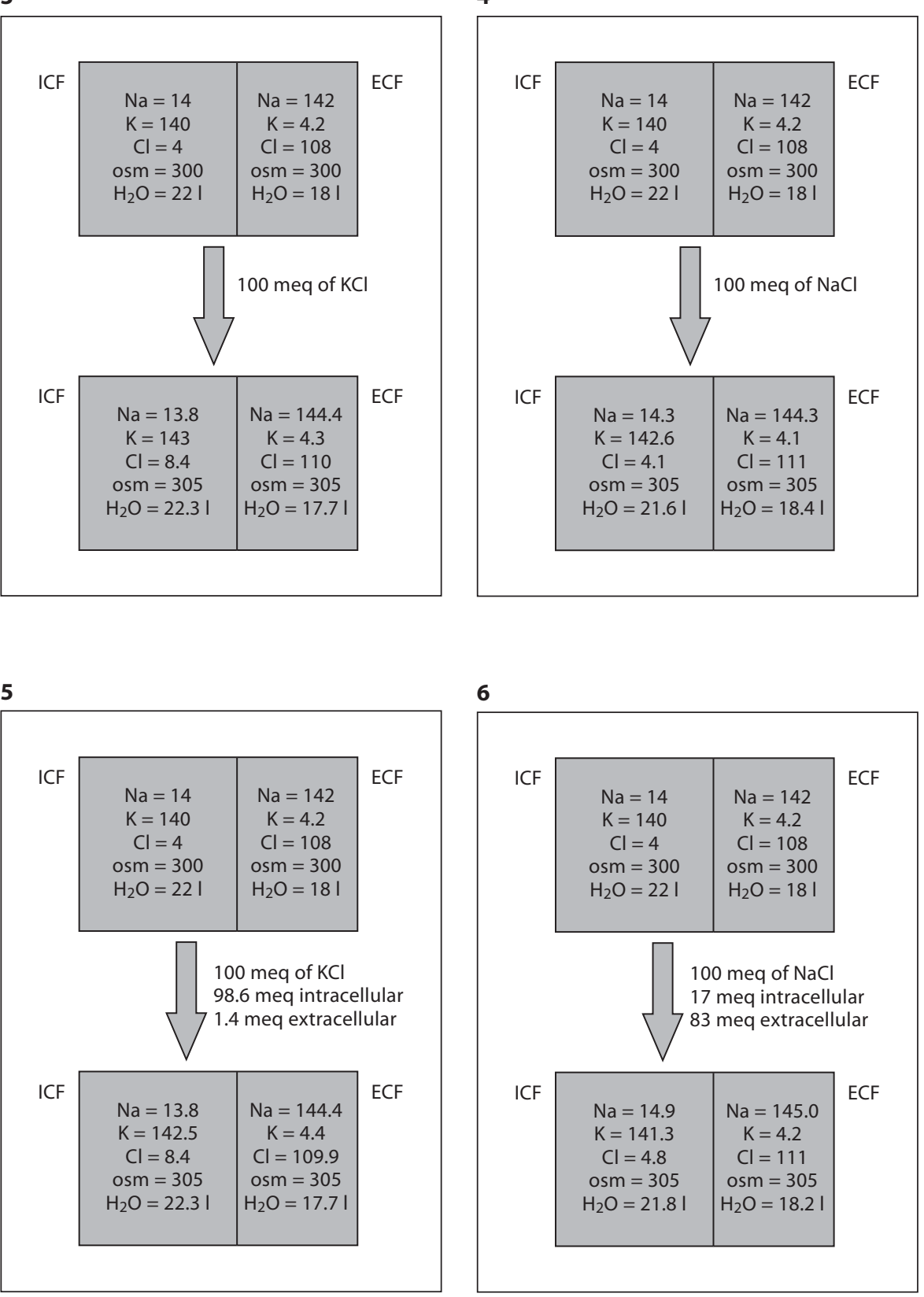

6

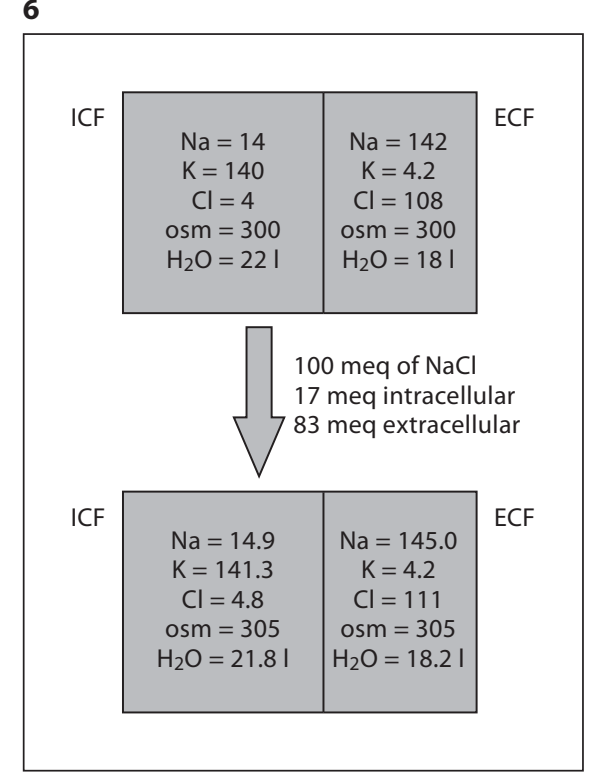

$\times 40 \mathrm{l})+200 \mathrm{mosm}] / 40 \mathrm{l}\}$. If all the $\mathrm{KCl}$ goes intracellularly, the total number of osmoles extracellularly has remained the same, and thus the extracellular water has decreased from 18 to 17.71 [ $(300 \mathrm{mosm} / \mathrm{l} \times 18 \mathrm{l}) / 305$ mosm/l]. The serum sodium concentration has now increased from 142 to $144.4 \mathrm{meq} / \mathrm{L}$ [(142 meq/L $\times 18 \mathrm{l}) /$ 17.7 l]. Similarly, 100 meq of $\mathrm{NaCl}$ will raise it from 142 to $144.3 \mathrm{meq} / \mathrm{L}$ (fig. 4). Again, giving $100 \mathrm{meq}$ of $\mathrm{NaCl}$ will increase the plasma osmolality from 300 to $305 \mathrm{mosm} / \mathrm{l}$ $\{[(300 \mathrm{mosm} / \mathrm{l} \times 40 \mathrm{l})+200 \mathrm{mosm}] / 40$ l $\}$. If all the $\mathrm{NaCl}$ stays extracellularly, the total number of osmoles intracellularly has remained the same, and thus the intracellular water has decreased from 22 to 21.61 [(300 mosm/l $\times 22$ 1)/305 mosm/l]. Thus, the extracellular water has increased from 18 to 18.41 . The serum sodium concentration has now increased from 142 to $144.3 \mathrm{meq} / \mathrm{L}\{[(142$ $\mathrm{meq} / \mathrm{L} \times 18 \mathrm{l})+100 \mathrm{meq}] / 18.4 \mathrm{l}\}$.

If one makes the five assumptions above but assumes that $\mathrm{KCl}$ and $\mathrm{NaCl}$ will distribute evenly in the intracellular and extracellular space according to their preexist- 


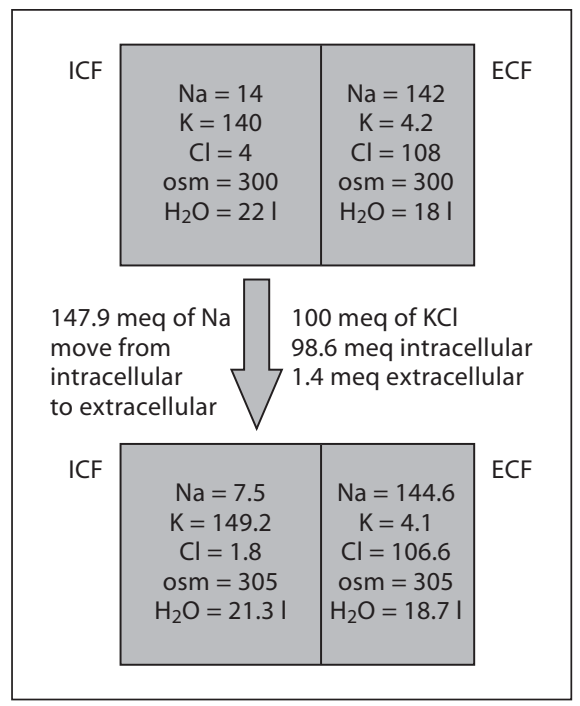

Fig. 7. Electrolyte concentrations before and after administration of 100 meq of $\mathrm{KCl}$. Assuming: (1) two-compartment model, (2) ionic osmolality of 1.0, (3) complete osmotic equilibrium between the compartments, (4) $\mathrm{KCl}$ distributes in intracellular and extracellular fluids, (5) intercompartmental movement of $\mathrm{Na}$ with $\mathrm{K}$ administration. Ignoring: (1) the Gibbs-Donnan effect, (2) nonosmotically active $\mathrm{Na}$ and $\mathrm{K}$.

Table 1. Sodium concentration of some bodily fluids

\begin{tabular}{ll}
\hline Bodily fluid & Na concentration, meq/L \\
\hline Urine & $40-60$ \\
Stool & $<50$ \\
Sweat & $36-56$ \\
Spit & 15 \\
\hline
\end{tabular}

ing concentrations in the compartments, then the following will happen. Administration of $100 \mathrm{meq}$ of $\mathrm{KCl}$, will lead to $98.6 \mathrm{meq}$ to go intracellularly and $1.4 \mathrm{meq}$ to stay extracellularly. This will lead to an increase in serum sodium concentration from 142 to 144.4 too (fig. 5). Administration of 100 meq of $\mathrm{NaCl}$ on the other hand, will lead to $83 \mathrm{meq}$ to stay extracellularly and $17 \mathrm{meq}$ to go intracellularly. The corresponding rise in serum sodium concentration would be from 142 to 145 meq/L (fig. 6).

Finally, if one assumes the first four assumptions above, but then assumes that for every 2 molecules of potassium moving intracellularly, 3 molecules of sodium will move out of the cell as happens with the $\mathrm{Na}$ /KATPase, then the following will happen. Administration of 100 meq of KCl, will lead to 147.9 meq of Na to move extracellularly, and serum sodium concentration will increase from 142 to $144.6 \mathrm{meq} / \mathrm{L}$ (fig. 7).

Although the modifications made to the Edelman equation and the equivalence of sodium and potassium help us understand the complexities of sodium concentration problems, the newer equations are so far not useful clinically as there are so many assumptions made with these equations that the simpler formulas may prove to be just as accurate in predicting serum sodium concentration.

\section{Normal Sodium Balance}

Amazingly, the body is able to maintain serum sodium concentration within a very narrow range (140 \pm $1 \mathrm{meq} / \mathrm{L})$. Understanding the mechanism of this regulation is crucial in order to comprehend disease states. On a qualitative basis we take in hyponatric fluid and we excrete hyponatric fluid too, thus maintaining normal serum sodium concentration. Simply, we drink water rather than isotonic saline. This is not always the case with patients in the intensive care unit unable to drink who normally receive high intravenous rates of isotonic saline. Not only urine sodium concentration is almost always significantly below $140 \mathrm{meq} / \mathrm{L}$, but also the same is true for stool, sweat, saliva and other bodily fluids (table 1) [10, 11]. More importantly, the urine sodium plus potassium concentration is also usually below $140 \mathrm{meq} / \mathrm{L}$.

On a quantitative basis, if the serum sodium concentration increases from 140 to $141 \mathrm{meq} / \mathrm{L}$, the sense of thirst will make us drink water and subsequently lower the serum sodium concentration to $140 \mathrm{meq} / \mathrm{L}$ again (fig. 8). Thus, it is easy to see that the only way to become hypernatremic is to have lost the sense of thirst or access to water. On the other hand, if serum sodium concentration goes from 140 to $139 \mathrm{meq} / \mathrm{L}$, then vasopressin secretion would be shut off and water excretion in the kidneys will bring the serum sodium concentration back to 140 meq/L. Again, one can see that abnormalities in vasopressin secretion are the main reason for hyponatremia, whether it is appropriate or inappropriate.

\section{Hypernatremia}

The best way to understand the management of hypernatremia is to categorize it into 2 different circumstances most commonly encountered in clinical medicine. The 


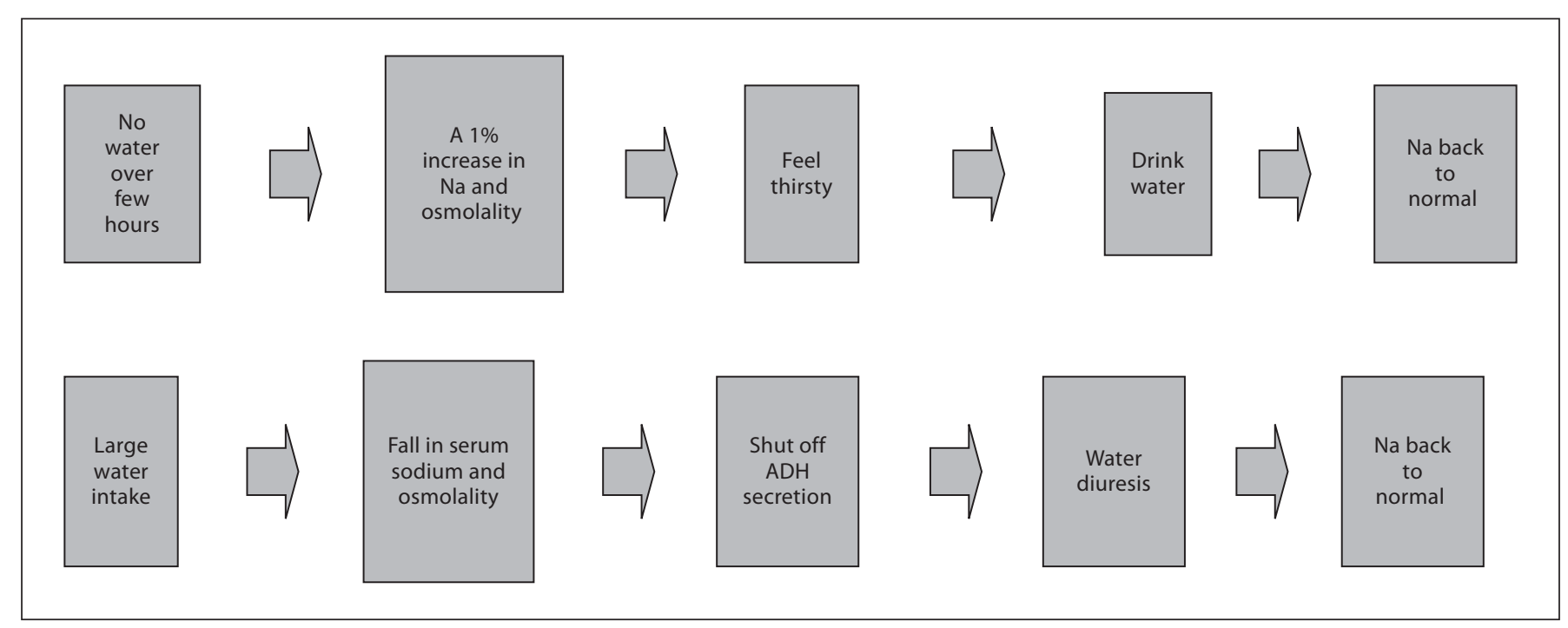

Fig. 8. Normal sodium balance.

management is similar but slightly different in each of these situations, emphasizing that in all of these cases the patient has either lost the sense of thirst or is unable to access water (i.e. intubated in the intensive care unit).

The typical patient in the first situation is the elderly nursing home resident with dementia who has lost the sense of thirst. The patient is brought to the emergency room and has a serum sodium concentration of for instance $170 \mathrm{meq} / \mathrm{L}$, and there may or may not be coexisting acute illnesses. The development of hypernatremia in this patient has occurred slowly over many days and the treatment should thus be gradual. In fact, if one assumes that the patient drinks $450 \mathrm{ml}$ of water a day and takes in 0.5 $\mathrm{g}$ /day of sodium and potassium each (patient is hardly eating and drinking), makes $500 \mathrm{ml}$ of urine/day (patient is oliguric because of dehydration) which has a sodium concentration of $40 \mathrm{meq} / \mathrm{L}$ and potassium concentration of $30 \mathrm{meq} / \mathrm{L}$ and has total body water of 30 liter, one can calculate that the development of hypernatremia has occurred over 138 days (or almost 5 months). It is clear that we should not correct this patient's serum sodium concentration rapidly. In fact even the recommended correction of $10 \mathrm{meq} / \mathrm{L} /$ day may be too fast pending further studies [12]. The latter patient is dehydrated and volume depleted, and since sodium correction should be slow, it is probably indicated to begin treatment with isotonic saline and then switch to a less hypertonic solution depending on the response of serum sodium concentration. The isotonic saline infusion can result in an increase in serum sodium concentration depending on the urine sodium and potassium concentration and the urinary volume (another words the electrolyte free water excretion). In our opinion, this patient should have his/her serum sodium concentration corrected very slowly and may not necessarily need to go home with a normal serum sodium concentration. On the other hand if a similar patient drinks $200 \mathrm{ml}$ of water a day and takes in $1 \mathrm{~g} /$ day of sodium and potassium each, makes $500 \mathrm{ml}$ of urine/day which has a sodium concentration of $40 \mathrm{meq} / \mathrm{L}$ and potassium concentration of $30 \mathrm{meq} / \mathrm{L}$ and has total body water of 30 liter, the calculation for development of hypernatremia is over 12 days only. However, the former situation is probably more frequent, as the latter situation will require an abrupt change in mental status as the fluid intake is so low.

Next is the patient in the intensive care unit who has developed acute renal failure [13]. He is intubated and on mechanical ventilation and does not have free access to water. At the beginning of his illness when he first developed sepsis and hypotension, he received many liters of isotonic saline. At this time he had developed acute renal failure and was not making much urine. His serum sodium concentration has remained normal despite having an intake consisting mainly of isotonic saline because of his low urine output (serum sodium concentration stays at the normal level because he is not losing much hypotonic fluids even though he is receiving isotonic fluids). The hypernatremia arises when he starts recovering renal function, making 3-4 liter a day of urine with low sodium and potassium concentration. At this time, he is still re- 
ceiving isotonic fluid for the most part, while losing many liters of relatively electrolyte-free urine, leading to an increase in serum sodium concentration. The serum sodium concentration rises by $4-6 \mathrm{meq} / \mathrm{L} / \mathrm{day}$. For example, this patient may be making 2 liter of urine with a urine $\mathrm{Na}$ concentration of $32 \mathrm{meq} / \mathrm{L}$ and urine $\mathrm{K}$ concentration of $45 \mathrm{meq} / \mathrm{L}$. Assuming a starting serum sodium concentration of $140 \mathrm{meq} / \mathrm{L}$, the electrolyte-free water excretion would be 0.9 liter. If the patient does not have any intake and has no other output, then the serum sodium concentration the next day would be $142.6 \mathrm{meq} / \mathrm{L}$ (the total body water is 50 liter as the patient has anasarca from earlier saline administration $),[(140 \mathrm{meq} / \mathrm{L} \times 50 \mathrm{l})-(45 \mathrm{meq} / \mathrm{L}$ $+32 \mathrm{meq} / \mathrm{L}) \times 2] / 48 \mathrm{l}$.

This situation is probably by far more common than the nursing home patient. The treatment of this patient should consist of mainly free water and correction of serum sodium quickly is not to be feared as hypernatremia has developed over a few days too. This patient should have as little sodium intake as possible as he has massive amount of extra sodium already (even half isotonic saline should be avoided). Also this patient is not volume depleted as earlier he has received many liter of fluids without making much urine and has extensive edema and often anasarca. The usual mistake in this case is not giving enough free water. Four factors combine to cause the hypernatremia in this patient. First, the patient is unable to access water as he is intubated. In fact, a similar patient who is not in the intensive care unit will not develop hypernatremia as they would be able to drink water. Second, this patient has renal failure (thus limiting the ability of the kidneys to make concentrated urine). With normal renal function, we are able to maximally concentrate our urine and have large excretion of sodium and potassium (people with normal renal function can increase urine sodium concentration dramatically with saline administration). Third, this patient is losing large amounts of fluid (at least 1-2 1/day). Most commonly, this occurs in the setting of high urine output after recovery of tubular necrosis, but can also happen with even large amounts of diarrhea. Fourth, commonly this patient has a high serum urea concentration which competes with sodium and potassium for urinary excretion.

\section{Conclusion}

In summary, four factors combine to lead to hypernatremia in a great majority of patients who develop this disorder. First and foremost, the patient has lost the sense of thirst or access to water. If this was not the case, the patient would drink their way out of hypernatremia in spite of the presence of other factors that may lead to hypernatremia. Because of this factor, hypernatremia in the hospital mostly occurs in patients in the ICU, intubated on mechanical ventilation. Less commonly, confused patients on the regular hospital wards can get hypernatremic. Second, there usually is an impaired ability to concentrate the urine. Even though this happens in cases of diabetes insipidus, it is much more common in the setting of renal failure whether it is acute or chronic. If a person with normal renal function and normal renal concentrating ability receives high rate of isotonic saline $(2 \mathrm{l} / \mathrm{h})$ for $1 \mathrm{~h}$, their urine osmolality would be in the order of 600-700 mosm/l, their urine sodium concentration in the order of $110-200 \mathrm{meq} / \mathrm{L}$ and their urine potassium concentration would be in the order of $40 \mathrm{meq} / \mathrm{L}$ [14]. Thus, they would not develop significant hypernatremia despite making large amounts of urine even if there is an impairment in the sense of thirst. Patients with kidney disease are unable to concentrate their urine to 600-700 mosm/l and in fact most often their urine osmolality is only in the order of 300-450 mosm/1 [13]. This limits the patient's ability to excrete the extra sodium compared to people with normal kidney function. Volume-depleted patients, as happens in the nursing home patients, may also be unable to excrete large sodium loads because of the kidneys' role in trying to correct the low volume state by reabsorbing sodium (although this occurs much less commonly). Third, the high serum urea concentration leads to urea competing with sodium to be excreted in the urine. We rather think of it as urea competing with electrolytes than urea inducing osmotic diuresis, because here the urine osmolality is limited by the renal failure. Thus, even though the high urea excretion may lead to more water excretion, it would not lead to more electrolyte excretion as the osmolality of the urine is fixed at $300-450 \mathrm{mosm} / \mathrm{l}$. One can think of it as: the high serum sodium and urea concentrations lead them to compete to get out into the urine which has limited ability to excrete osmoles. Lastly, the large output, whether it is urine (most commonly) or stool, leads to a large water excretion which is not balanced by large sodium and potassium excretion. Even though the larger the output the more likely it is that hypernatremia will develop, increases in serum sodium concentration can happen with outputs as low as one liter per day.

Often, patients with hypernatremia in the intensive care unit are not volume depleted despite having large outputs as they have received large volumes of fluid ear- 
lier in the course of their illness and have had much less output for many days [13]. Thus, hypernatremia often develops in the setting of large outputs and not in the setting of volume depletion.

\section{Disclosure Statement}

The authors have no conflicts of interest to declare.

\section{References}

1 Edelman IS, Leibman J, O’Meara MP, Birkenfeld LW: Interrelations between sodium concentration, serum osmolality and total exchangeable sodium, total exchangeable potassium and total body water. J Clin Invest 1958;37:1236-1256.

$\checkmark 2$ Adrogue HJ, Madias NE: Hypernatremia. N Engl J Med 2000;342:1493-1499.

3 Anderson RJ, Chung HM, Kluge R, Schrier RW: Hyponatremia: a prospective analysis of its epidemiology and the pathogenetic role of vasopressin. Ann Int Med 1985;102:164-168.

4 Kurtz I, Nguyen MK: Evolving concepts in the quantitative analysis of the determinants of the plasma water sodium concentration and the pathophysiology and treatment of the dysnatremias. Kidney Int 2005;68:19821993.
5 Titze J, Shakibaei M, Schafflhuber M, Schulze-Tanzil G, Porst M, Schwind KH, Dietsch P, Hilgers KF: Glycosaminoglycan polymerization may enable osmotically inactive $\mathrm{Na}^{+}$ storage in the skin. Am J Physiol Circ Physiol 2004:287:H203-H208.

6 Rose BD: New approach to disturbances in the plasma sodium concentration. Am J Med 1986;81:1033-1040.

7 Nguyen MK, Kurtz I: New insights into the pathophysiology of the dysnatremias: a qualitative analysis. Am J Physiol Renal Physiol 2004;287:F172-F180.

$\checkmark 8$ Nguyen MK, Kurtz I: Correction of hypervolaemic hypernatraemia by inducing negative $\mathrm{Na}^{+}$and $\mathrm{K}^{+}$balance in excess of negative water balance: a new quantitative approach. Nephrol Dial Transplant 2008;23:2223-2227.

$\checkmark 9$ Bhave G, Neilson EG: Body fluid dynamics: back to the future. J Am Soc Nephrol 2011;22: 2166-2181.

$\checkmark 10$ Takamata A, Yoshida T, Nishida N, Morimoto T: Relationship of osmotic inhibition in thermoregulatory responses and sweat sodium concentration in humans. Am J Physiol Regul Integr Comp Physiol 2001; 280:R623-R629.
11 Murphy MS, Sibal A, Mann JR: Persistent diarrhea and occult VIPomas in children. BMJ 2000;320:1524-1526.

12 Burrows FA, Shutack JG, Crone RK: Inappropriate secretion of antidiuretic hormone in a postsurgical pediatric population. Crit Care Med 1983;11:527-531.

13 Sam R, Hart P, Haghighat R, Ing TS: Hypervolemic hypernatremia in patients recovering from acute renal failure in the intensive care unit. Clin Exp Nephrol 2012;16:136146.

14 Lobo DN, Stanga Z, Alastair J, Simpson D, Anderson JA, Rowlands BJ, Allison SP: Dilution and redistribution effects of rapid 2-litre infusions of $0.9 \%(\mathrm{w} / \mathrm{v})$ saline and $5 \%(\mathrm{w} / \mathrm{v})$ dextrose on haematological parameters and serum biochemistry in normal subjects: a double-blind crossover study. Clin Sci 2001; 101:173-179. 